\title{
ギリシア古代都市メッセネにおける劇場のローマ時代舞台建物の復元試案 A TENTATIVE RECONSTRUCTION OF THE ROMAN SCENE BUILDING OF THE THEATER IN ANCIENT MESSENE
}

\author{
岩田千穂*, 吉武隆一**, 伊藤 重 剛 $^{* * *}$ \\ Chiho IWATA, Ryuichi YOSHITAKE and Juko ITO
}

\begin{abstract}
Ancient Messene, Greece, was founded by Epameinondas in 369 B.C.. Kumamoto University Architectural Mission for Greek classical Architecture has surveyed, since 2007, the architectural remains of the theater including more than a hundred of blocks from walls, columns, etc., in order to reconstruct its form of 2nd century A.D. The authors analyzed each block in detail and tried to reconstruct the scene building which would have been built in 2nd century A.D. and reached the conclusion that the scene building was $12.2 \mathrm{~m}$ high and two-storied with rows of Corinthian, Lotus-Acanthus, and Ionic columns on the front.
\end{abstract}

Keywords: Ancient Greece, Roman era, Messene, Theater, Scene building, Reconstruction 古代ギリシア，ローマ時代，メッセネ，劇場，舞台建物，復元

\section{1. 序論}

\section{1-1. 研究背景}

ギリシアのペロポネソス半島南西部にある古代都市メッセネは、 紀元前 369 年にエパミノンダスにより建設された都市である ${ }^{1)}$ 。都 市の北にはイトメ山、東にはエヴァ山があり、周囲には全長約 $9 \mathrm{~km}$ に及ぶ市壁が築かれていた。これらの山の山裾のゆるやかな傾斜地 に主要な公共施設が建設され、ここが都市の中心部となっている。 過去の発掘調査により、スタディオン、アスクレピオス神域、アゴ ラ、泉、劇場など、都市の主要な公共施設が出土した。これらのうち、 劇場は、アゴラの北西隅から約 $34 \mathrm{~m}$ 西にあり、自然の斜面を利用 して作られており、オルケストラ、客席、客席を支えた後壁、パラ ドスの壁、舞台建物、建築部材などが出土している。

メッセネの遺跡は、19 世紀末から 20 世紀前半にかけて、Th. Sophoulis 氏 ${ }^{2} 、$ G. Oikonomos 氏 ${ }^{3)}$ により発掘がおこなわれた。その後、 1957 年から 1974 年にかけて、考古学者のオルランドス氏の指揮下 で長期にわたる発掘がおこなわれたが、最終的な発掘報告書は発行 されていない" ${ }^{4)}$ それ以降しばらくは、発掘がおこなわれていなかっ たが、1987 年からメッセネ考古学協会（会長:元クレタ大学教授、P. テメリス氏）による大規模な発掘が開始され、現在も継続して調査 がおこなわれている5

劇場の発掘は、メッセネ考古学協会により 1997 年から開始され、
発掘がひと段落した 2010 年以降は、現場での修復作業がおこなわ れている。劇場の建設時期を直接特定できる碑文などの考古学的証 拠は、これまでには発見されていない。テメリス氏は、発掘遺物、 建築的特徴、歴史的背景などから、前 3 世紀ごろ最初の劇場が建設 され、後 2 世紀ごろにローマ式劇場に改築、後 3 世紀ごろ再び改修 されたと推定している ${ }^{6}$ 。舞台建物については、紀元前 1 世紀まで のヘレニズム時代に最初の舞台建物が建設され、後 2 世紀ごろロー マ式劇場に改築した際に、新しい舞台建物が建設されたとされてい る。これは、発掘調査により、ローマ式の舞台建物と、その舞台床 下からへレニズム時代の舞台建物の基礎の痕跡や円柱部材が、さら に舞台建物の東方で舞台収納庫と思われる遺構が出土したことなど が、その根拠である。本稿で分析対象としているのは、ローマ式の 舞台建物で、その平面形式や、遺構近くからトライアヌスとハドリ アヌスの彫像が出土したことから、発掘者は後 2 世紀に建設された ものと判定している。

筆者ら熊本大学ギリシア古代建築調査団 (団長 : 伊藤重剛 ) は、 2007 年から 2011 年までの毎年 8 月から 9 月にかけて、建築班とし て当該劇場の建築調査をおこなってきた。調査団の調査内容は、劇 場の建築遺構や建築部材の実測、写真撮影、そして詳細な観察記録 をとることである。

\footnotetext{
${ }^{*}$ 熊本大学大学院自然科学研究科 大学院生 $\cdot$ 修士 (工学

Student, Graduate School of Science and Technology, Kumamoto University, M. Eng.

** 熊本大学大学院先導機構 特任助教·博士 (工学) Assistant Prof., Priority of Organization for Innovation and Excellence, Kumamoto University, Dr. Eng.

*** 熊本大学大学院自然科学研究科 教授・博士 (工学 $)$

Prof., Graduate School of Science and Technology, Kumamoto University, Dr. Eng.
} 


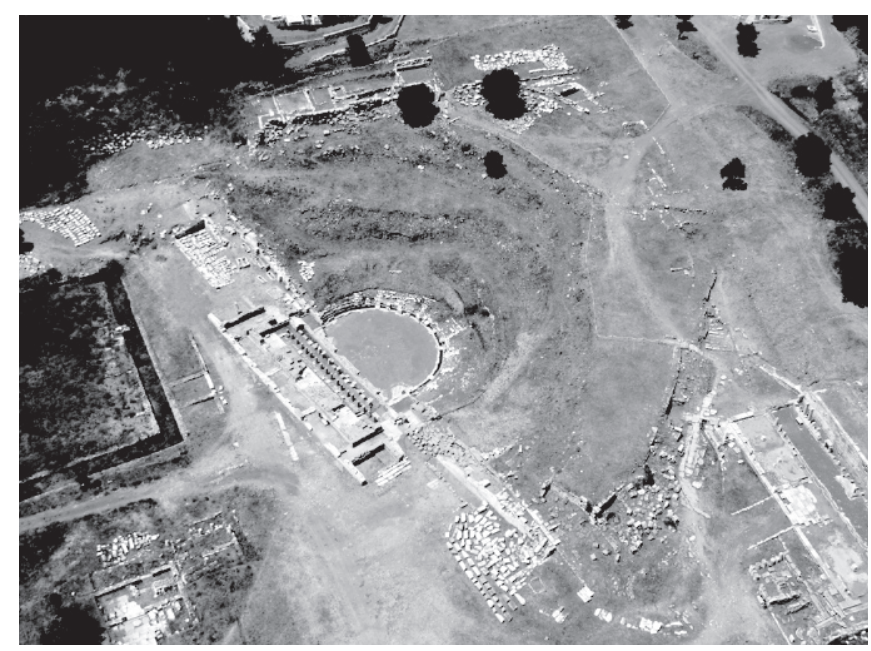

写真 1 劇場鳥瞰写真（メッセネ考古学協会提供）

\section{1-2. 本研究の目的と研究方法}

メッセネの劇場に関する研究報告として、これまでに、発掘者の テメリス氏による発掘年報が発表されている7”。また、調査団は、 建築学会九州支部大会にて、2007 年から 2010 年までの調査成果の 報告を抢こなっている ${ }^{8)}$

本稿の目的は、現地の調查で得られた成果に基づき、後 2 世紀の 舞台建物 ${ }^{9}$ を復元することである。本稿では、まず劇場全体の概要 と、舞台建物の遺構や建築部材の現状を述べる。さらに、これらを 分析した結果を報告する。そして、分析結果に基づき舞台建物全体 の復元を試みる。

1-3. 劇場に関する既往研究

紙数の関係で、既往研究については詳述しないが、代表的な研究 書としては、ビーバーによる劇場建築の歴史を通史的に著したも のや、シアーによるローマ劇場の研究書が挙げられる ${ }^{10)}$ 。個別の 劇場に関する復元研究は、各遺跡の発掘報告書に多く見られる。た とえば、アテネのディオニソス劇場や、サブラサの劇場などが挙げ られる ${ }^{11)}$ 。メッセネの劇場は、近年発見された新出資料であり、劇 場建物の本格的な復元研究をおこなうのは、著者らが初めてである。

\section{2. 劇場遺構の現状 (写真 1、図 1、2)}

劇場は、南北、東西ともに全長約 $100 \mathrm{~m}$ で、客席が南向きに造ら れており、その周囲は石積みの後壁で支えられている。客席は、ほ とんど崩壊した状態で出土したが、最下段から 2,3 段程度までは 残っている部分があり、最前列に 2 席のみ背もたれ付きの貴賓席が 出土している。客席を支える後壁は、劇場の東西で長さ $60 \mathrm{~m}$ にわ たって出土している。西側では、ルスティカ仕上げの石材を積み、 大小 4 つの階段で客席と外部とをつないでいる。一方、東側の石積 みに使用された石材の仕上げは西側の石材と異なり、表面の突出が 少ない。また、壁には、 $3 \mathrm{~m} \sim 4 \mathrm{~m}$ おきにバットレスが付けられている。

オルケストラは、円の 4 分の 1 を舞台建物が切り取る形になっ ている。オルケストラの直径は、幅約 $0.5 \mathrm{~m}$ のエウリポス (溝) の

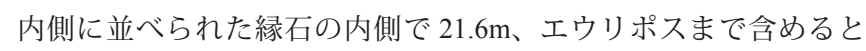
$23.6 \mathrm{~m}$ である。オルケストラの床面に、赤、白、灰などの約 $20 \mathrm{~cm}$ 角の四角い大理石板が部分的に残っている。

客席の南側には舞台建物があるが、詳細は次章で述べる。舞台建

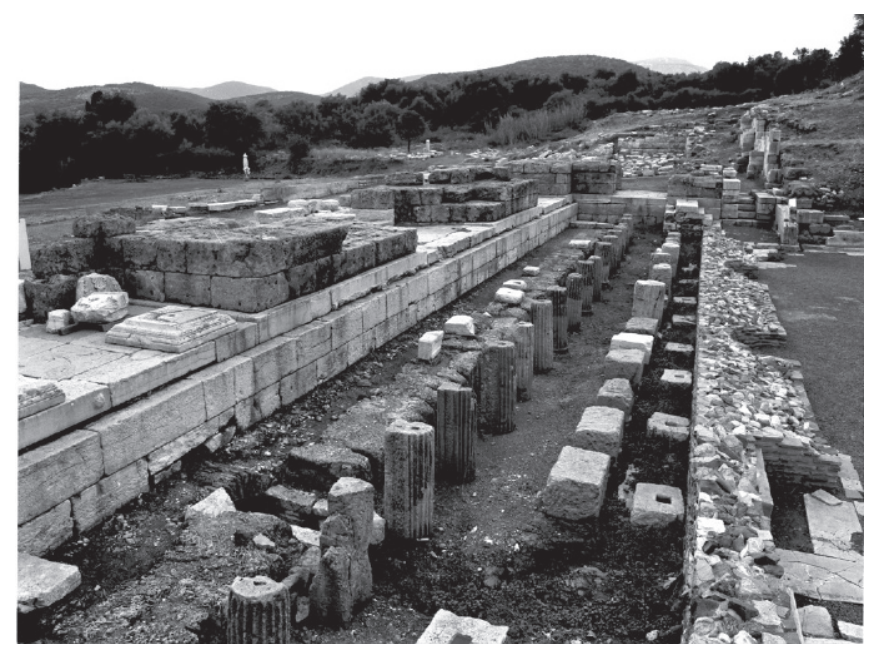

写真 2 舞台建物（左）と舞台床下（中央部）

物の東には、可動式の舞台背景を収納するための舞台収納庫と思わ れる遺構が出土した。遺構の西端から東側の壁までの長さが 27.55 $\mathrm{m}$ 、幅が $8.13 \mathrm{~m}$ である。この中に、溝が付けられた石材がレール 状に並べられた遺構が、東西に平行に 3 本出土した。

客席と舞台建物との間は、役者や観客が通るパラドスという通路 となり、客席側の壁は、客席を支える壁となる。西パラドスの壁は、 舞台建物の壁とほぼ平行で、矩形あるいは L 字型に成形した石灰 岩を精緻に積んでいる。ところが、この壁は、オルケストラから西 へ約 $20 \mathrm{~m}$ の地点で、下部のみが外側へ 7 度曲がっている。一方、 東側のパラドスの壁は、ポロス材の石積みと、その上部が崩れた状 態で発見された。この壁は、舞台建物の壁と平行でなく、5 度角度 をなしている。

\section{3. 舞台建物の現状（写真 2、図 3、4）}

現在残っている後 2 世紀の舞台建物は、東西 $46.6 \mathrm{~m}$ 、南北 $15 \mathrm{~m}$ で ある。オルケストラに面する部分に、舞台の最前面となるプロスケ ニオンの壁、その後ろに舞台がある。その背後にはスカエナエ・フ ロンスが、そのさらに後方にポストスケニオンがある。スカエナエ・ フロンスには3つのニッチがあり、それぞれのニッチ背後には出入 口がある。舞台袖にも出入口があり、ポストスケニオンと通路でつ ながっている。遺構を詳細に観察すると、建物の表面にダボ穴やク ランプ穴が見られる。また、出土部材の中には再加工の痕跡が観察 されるものがある。これらのことから、この舞台建物は、ヘレニズ ム時代の舞台建物もしくは他の建物の建築部材を再利用し、それら に新しく作った部材を加えて建設されたと考えられる。以下、遺構 の各部分について詳しく述べる。

\section{3-1. 舞台建物主要部の躯体}

舞台建物の躯体は、ポロス材や石灰岩で造られている。現在、石 灰岩が地表から 3 段積まれ、3 段目の上面がニッチや舞台袖の出入 り口付近の床面となっている。1、2段目に使用された石材は、高 さ $0.42 \mathrm{~m} \sim 0.5 \mathrm{~m}$ で、 3 段目の石材は、ニッチ部分では高さ約 $0.3 \mathrm{~m}$ 、 それ以外の部分では、高さ約 $0.4 \mathrm{~m}$ である。ニッチ以外の部分では、 さらにこの上に、高さ $0.43 \mathrm{~m} \sim 0.50 \mathrm{~m}$ のポロス材を積み、壁を立 ち上げている。現在、ポロス材が 3 段積まれたものが最高で、ニッ チ床面からの高さは最高 $1.442 \mathrm{~m}$ である。 

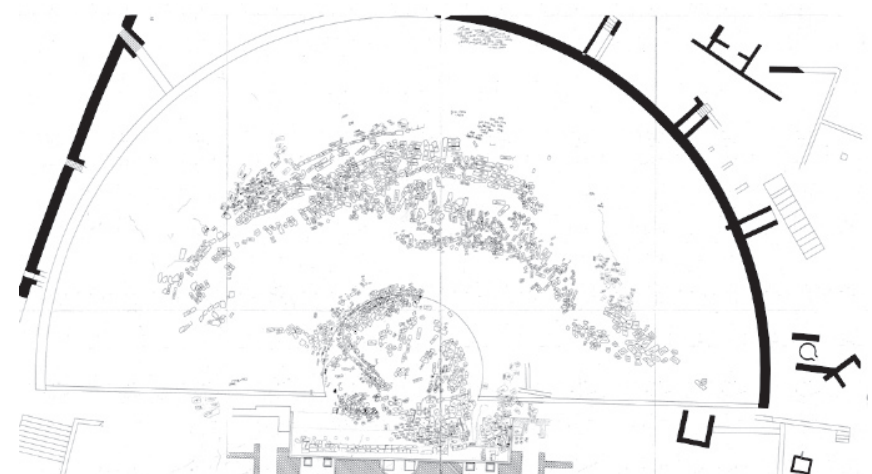

図 1 劇場の出土状況図 (メッセネ考古学協会作成)

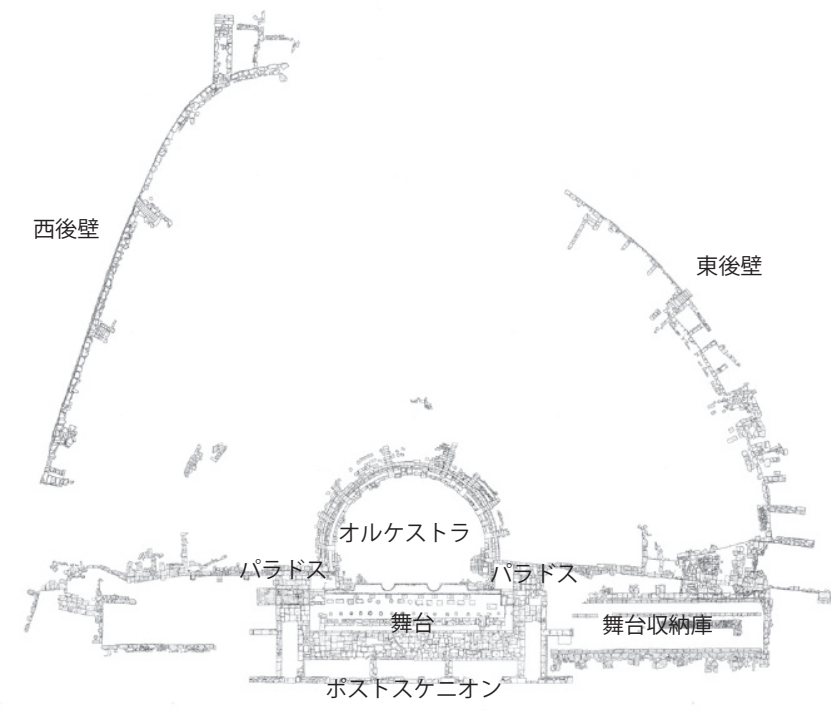

図 2 劇場全体の現状平面図

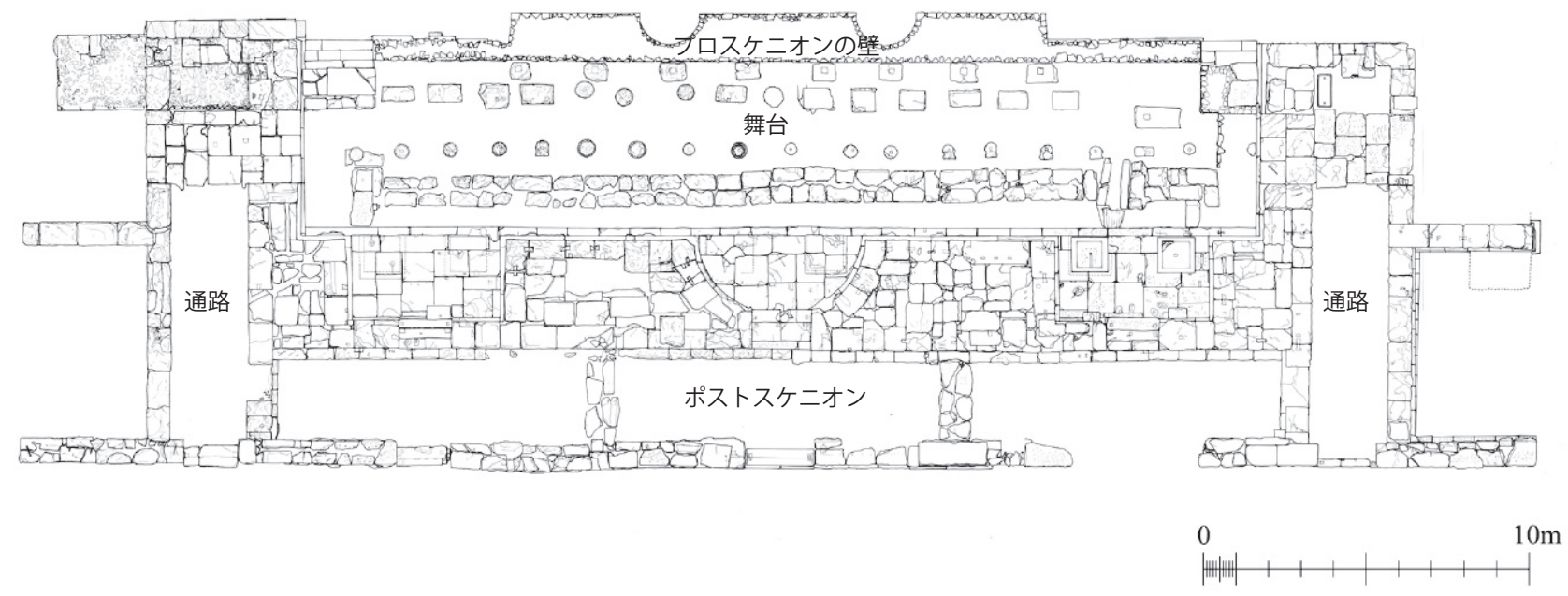

図 3 舞台建物の現状平面図

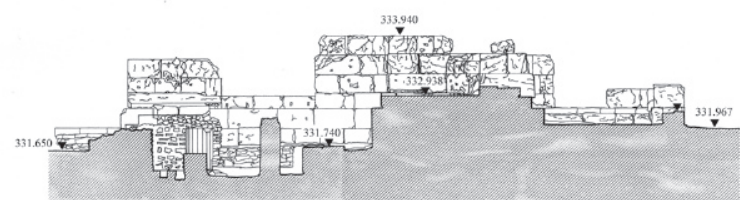

中央ニッチの南北断面（東を見る）

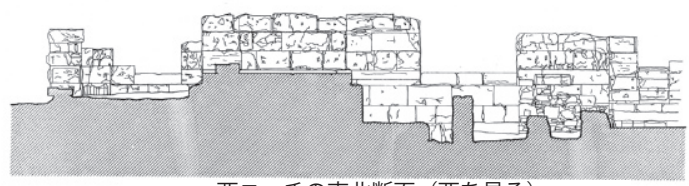

西ニッチの南北断面（西を見る）

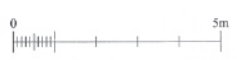

図 4 舞台建物の現状断面図

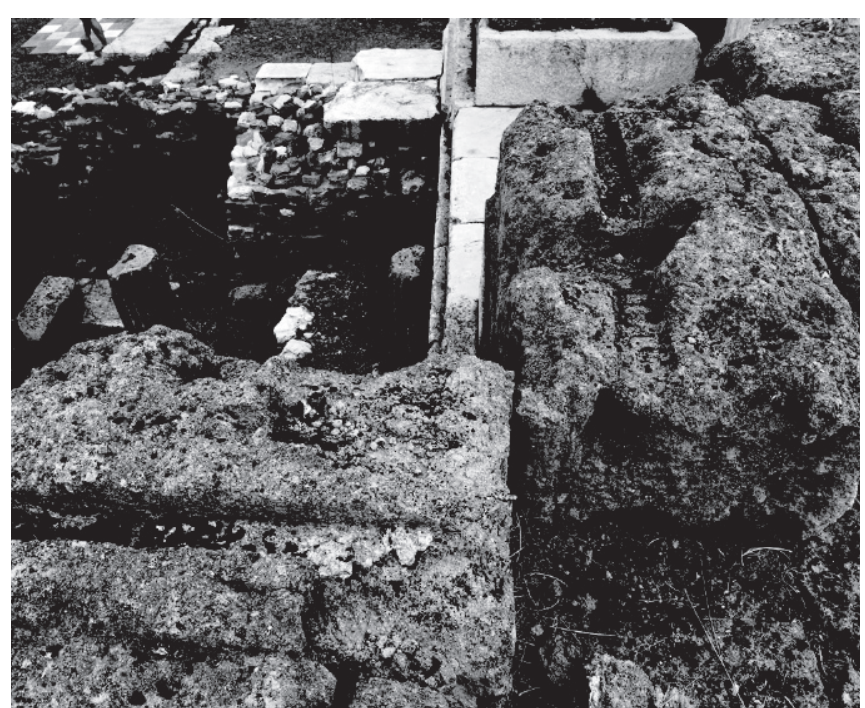

写真 3 スカエナエ・フロンスのポロス壁の上面に付けられた溝の痕跡 


\section{3-2. プロスケニオンの壁}

プロスケニオンの壁は、舞台前面のオルケストラと接する部分 に造られた壁で、舞台建物の正面壁から $5.27 \mathrm{~m}$ 離れた位置にあり、 全長 $25.47 \mathrm{~m}$ 、幅最大 $1.55 \mathrm{~m}$ で、高さは約 $1 \mathrm{~m}$ である。壁の中央部

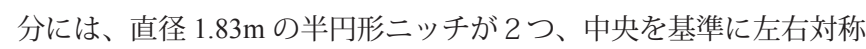
に配置されている。壁の端部では壁が薄くなり、厚さ $0.60 \mathrm{~m}$ となる。 この壁は、棟瓦造の躯体に漆喰を塗り、その上に厚さ $1.5 \mathrm{~cm} \sim 2.0 \mathrm{~cm}$ の大理石化粧材を貼って仕上げたようで、壁の東側でその痕跡が確 認された。

\section{3-3. 舞台}

舞台があった部分は、現在、舞台床が失われ、舞台下が露出した 状態である。舞台下の地表面には、ポロス材あるいは石灰岩で造ら れた円柱や、石材の列が並ぶ。また、ヘレニズム時代に建っていた 舞台建物のプロスケニオン部分と思われる遺構が、出土している。

プロスケニオンの壁から約 $2.5 \mathrm{~m}$ の位置に、ポロス材で造られた 円柱や半円柱付き角柱などが 18 本、舞台建物とほぼ平行に $1.25 \mathrm{~m}$ 〜 $1.85 \mathrm{~m}$ の間隔で並んでいる。礎盤付き円柱が 4 本、20 本のフルー トが付いた円柱が 8 本、 6 本のフルートが付く半円柱付き角柱が 5 本、角柱が 1 本ある。円柱上面とニッチ床面との高低差は、 $0.54 \mathrm{~m}$ 〜 $0.64 \mathrm{~m}$ である。角柱付き円柱の両側面には、幅約 $0.15 \mathrm{~m}$ の溝が あり、柱と柱との間に板材をはめるためのものであると考えられる。 このような部材の特徴から、これらの円柱は、ヘレニズム時代の舞 台建物のプロスケニオンを構成した部材であると考えられるが、形 の異なる柱が不規則に並べられていることから、後 2 世紀の舞台建 物を建設した際に、舞台床を支える柱として再利用されたと推察さ れる。

\section{3-4. 舞台建物のニッチ}

舞台の背後には、3つのニッチが造られている。中央のニッチが 最も大きく、直径 $5.01 \mathrm{~m}$ の半円形で、東西のニッチは幅 $4.58 \mathrm{~m}$ 〜 $4.59 \mathrm{~m}$ 、奥行き $2.58 \mathrm{~m} \sim 2.61 \mathrm{~m}$ の矩形である。オルケストラ床面と ニッチ床面との高低差は、 $1.288 \mathrm{~m}$ である。

各ニッチには、底面が約 1.20 m角のペデスタルの台座が 2 つず つ設置された痕が見られ、東側の矩形ニッチには実際にペデスタル の最下部の部材が 2 つ残っている。各ニッチ後方には、幅 $1.625 \mathrm{~m}$ 〜 1.782m の出入口があり、敷居が残っている。それらの両脇の壁 には、角柱の片蓋柱があった痕跡が確認される。

\section{3-5. ポストスケニオンと通路}

舞台建物の背後にある室はポストスケニオンと呼ばれ、役者の控 室や舞台への通路となっていた。当該遺構のポストスケニオンは、 石灰岩の仕切り壁により 3 室に分かれており、各室が 3 つのニッチ 後方にある出入口から舞台へ出入りできる。3 室のうち、中央の室 がやや広く、長さ $10.02 \mathrm{~m}$ で、東西の室が長さ $9.5 〜 9.55 \mathrm{~m}$ で、各 室の幅は $2.82 \mathrm{~m} \sim 2.91 \mathrm{~m}$ である。また、ポストスケニオンの東西 両端には、舞台両袖の出入口へ向かう全長約 $8 \mathrm{~m}$ 、幅約 $2.4 \mathrm{~m}$ の通 路が設けられている。この通路の北側には、舞台、東西両外側、そ してパラドスへ抜ける出入口があり、南側にも外部へ抜ける出入口 がある。

\section{4. 舞台建物の建築部材}

劇場遺構発掘時に、舞台建物を構成したと考えられる建築部材が
多く出土し、取り上げられて別所に保管されている。建築部材は、 大理石や石灰岩などで造られている。2007年から 2011 年の調査で、 約 150 部材の実測をおこない、125 部材の実測図を作成した。また、 客席部材約 500 個の寸法計測をおこなった。実測をおこなった 150 部材のうち、スカエナエ・フロンスの復元に用いた部材は、140 部 材である。以下、各部材の現状を述べる。

4-1. 礎盤

礎盤はほぼ全体が残っているものを 21 個実測した。メッセネの 礎盤は、上からトルス、スコティア、トルスが施されたいわゆるアッ ティカ式のモールディングのある部分と、その下のプリンスとが、 1つの石材で作られている。礎盤の上面には 1 つ、底面には 1 つま たは 3 つの゙ボ穴がある。礎盤の大きさはさまざまで、円形のプリ ンスを持つ部材と矩形のプリンスを持つ部材が混在している。

\section{4-2. 柱身}

柱身部材は、すべて割れて、いくつかの破片の状態で出土した。 接合可能な破片は接合され、ほぼ完全な姿に復元されている部材も ある。調査で実測した柱身は、ほぼ完全な形に復元されたものが 7 本、底面のみ残るものが 13 本、上面のみ残るものが 12 本である。 全長が判明している柱身は、高さにより明確に 4 種類に分けられる。 最も高い柱身が平均高さ $4.057 \mathrm{~m} 、 2$ 番目に高い柱身が高さ $3.524 \mathrm{~m}$ 、 3 番目に高い柱身が高さ $2.906 \mathrm{~m}$ 、そして最も低い柱身が高さ $2.329 \mathrm{~m}$ である。

柱身には、様々な材質の石材が使用されており、灰色花崗岩、赤 斑大理石、赤白の縞模様の大理石、薄緑の縞模様の大理石、灰色大 理石、粒が大きな灰色大理石、そして白色の結晶質大理石の、7 種 の石材を使用したことが確認された。劇場で出土した柱身部材は、 全体が一つの石材で造られている。柱身の上部には、トルスのモー ルディングが付き、下部には、 $0.1 \mathrm{~m}$ 程度の平縁が付いている。

\section{4-3. 柱頭 (図 5)}

柱頭は、合計 17 個の実測をおこない、2 個のコリント式柱頭、5 個のイオニア式柱頭、10 個のロータス・アカンサス式柱頭の 3 種 類がある。コリント式柱頭は、同種の柱頭部材破片が見つかってお り、実際は 2 個以上あったと考えられる。次に、イオニア式柱頭は、 装飾で見ると 2 種類出土している。ひとつは通常のイオニア式柱頭 で、1 個出土しており、もうひとつは渦巻が 4 隅に付くイオニア式 柱頭で、4 個出土している ${ }^{12}$ 。両者を比較すると、部材の高さや上面、 底面幅などに大きな差はない。最後に、ロータス・アカンサス式柱 頭は、ベル型のカラトスにロータスの葉とアカンサスの葉が 1 段ず つ付く ${ }^{13)}$ 。

4-4. アーキトレイブ・フリーズ (図 6)

アーキトレイブとフリーズは、柱の柱頭の上に載る梁部材である。 これらは、本来別々の部材であるが、メッセネの劇場の場合、1つ の部材として造られている。アーキトレイブ部分には、3段のファ スキアとその上にクラウニング・モールディングが施されており、 フリーズはシーマ・レヴェルサのモールディングになっている。出 土した部材は、高さが $0.6 \mathrm{~m}$ 程度の大きな部材と、高さが $0.3 \mathrm{~m}$ 程度 の小さな部材とに分かれる。高さ $0.6 \mathrm{~m}$ の部材は、前面および背面 にモールディングが施されており、フリーズやファスキアに装飾が 有るもの ${ }^{14)}$ と、無いものとがある。一方、高さ $0.3 \mathrm{~m}$ の部材は、前 面のみにモールディングが施され、背面は平滑に仕上げられ、ファ 
スキアやフリーズに装飾が施されたものは無い。

\section{4-5. ゲイソン (図 7)}

ゲイソンは、アーキトレイブ•フリーズの上に載る軒部材である。 部材ごとの加工精度には、かなりばらつきがある。また、部材の高 さが一定しておらず、上面が水平でないものが多い。このような上 面の公配は水勾配である可能性がある。しかし、勾配にばらつきが あることから、他の建物の部材を再加工してゲイソンを制作したた めか、施工䛊差とも考えられる。

当劇場の舞台建物から出土したゲイソンは、部材正面のモール ディングに施された装飾の有無により、明確に二分することができ る。一方は、心鏃装飾 (heart-and-dart) と舌葉装飾 (tongue-and-leaf) との浮彫装飾が施されており、もう一方は、施されていない。浮彫 装飾付きの部材は、正面の高さが平均 $0.309 \mathrm{~m}$ 、浮彫装飾のない部 材は、正面の高さが平均 $0.253 \mathrm{~m}$ である。

4-6. シーマ

シーマはゲイソンの上部に据えられる。これまでに実測した $4 つ$ の部材は全体的に高さが揃っており、平均高さ $0.197 \mathrm{~m}$ である。部 材正面のモールディングは、下段に大きなシーマ・レヴェルサが施 され、上部にカラスのくちばしの様な水切りが付けられている。

\section{4-7. 破風}

ほぼ完全な状態で発見された破風部材と思われるものは、長さ $2.113 \mathrm{~m}$ 、幅 $1.055 \mathrm{~m}$ で、正面の高さは $0.352 \mathrm{~m}$ である。また、正面 に三角形の破風の痕跡が観察される小さな破片が、4 個見つかって いる。これらは、全て大理石製で、破風の勾配は抢よそ $1 / 6$ である。
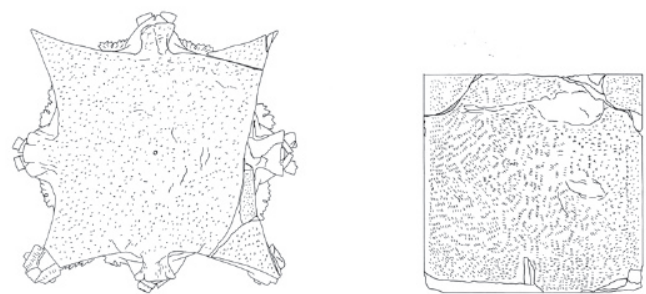

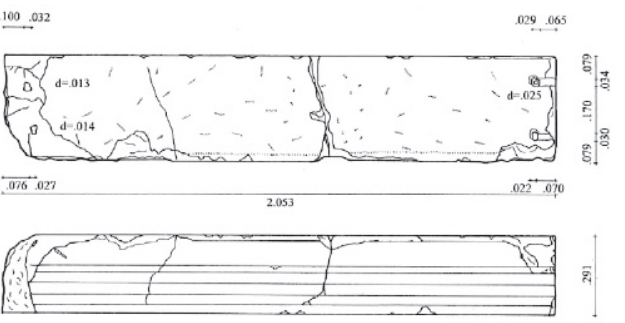

(ウ )
(ア )
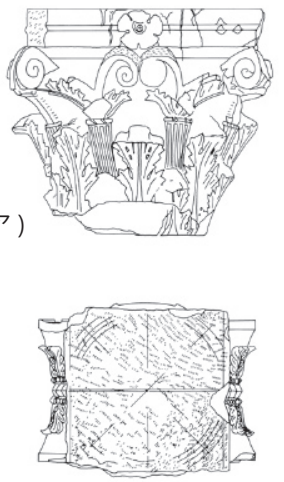

(ウ )

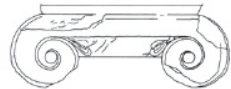

(イ )
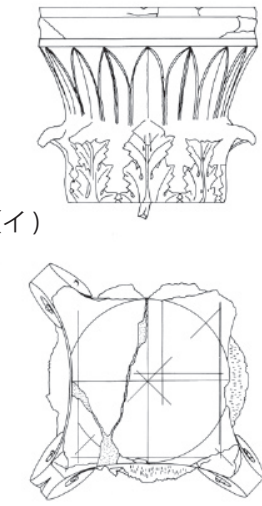

(I)

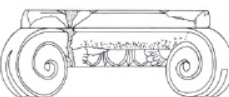

図 5 出土した柱頭

（ア）コリント式柱頭（No. B808）（イ）ロータス・アカンサス式柱頭（No. B1909） （ウ）通常のイオニア式柱頭（No B1912）（エ）四隅に渦巻が付くイオニア式柱頭 (No.B11085)
(ア )
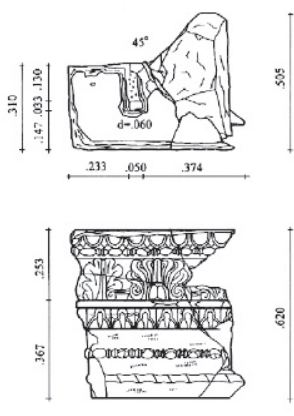

.657
(イ )

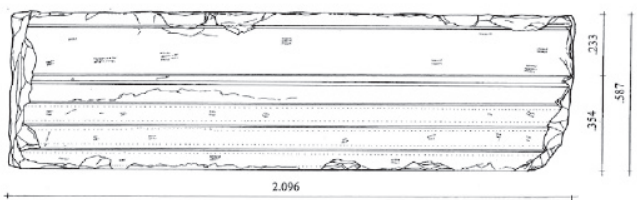

図 6 出土したアーキトレイブ・フリーズ

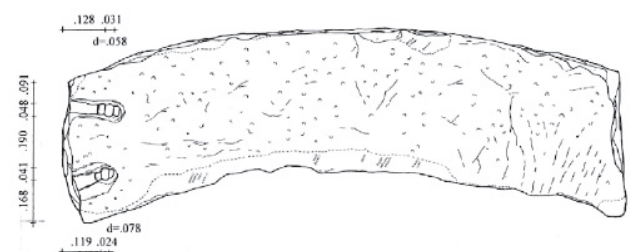

（ア）装飾が有る約 $0.6 \mathrm{~m}$ のアーキトレイブ・フリーズ（No. B66+1402）

\section{园6 出上したアーキトレイブ・フリーズ}

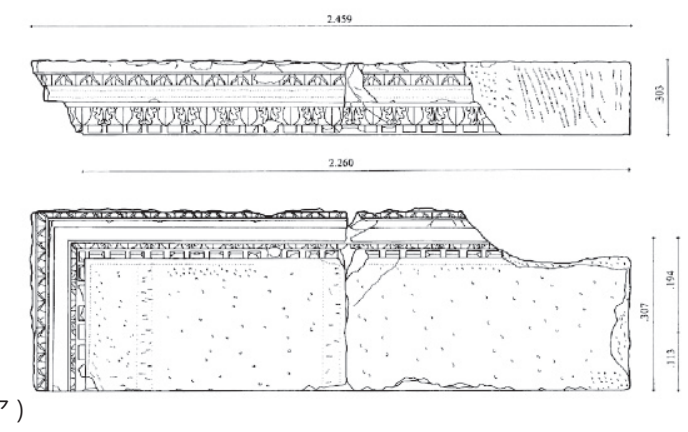

(イ)

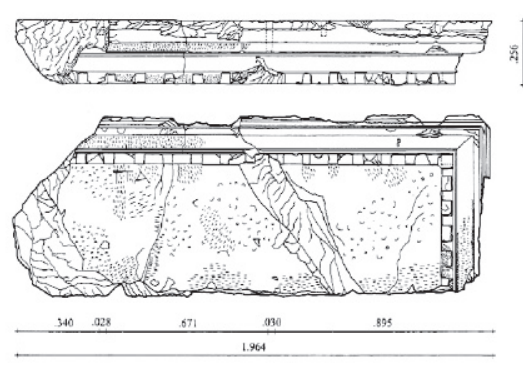

図 7 出土したゲイソン

（ア）モールデイングに装飾が有るゲイソン（No. B2）（イ）モールディングに装飾が無いゲイソン (No. B8) 


\section{5. 舞台建物の推定復元}

本章では、現地調査で得られた遺構と建築部材の情報をもとに、 舞台建物の復元を試みる。なお、各部復元寸法を決定する際は、平 均值をもって復元值とした。

\section{5-1. スカエナエ・フロンスの復元}

スカエナエ・フロンスは列柱で構成され、舞台建物の中では最も 多くの種類の部材が使用された部分である。

1）柱部材の分類と組み合せ

メッセネの劇場の柱は、礎盤、柱身、柱頭の 3 部材で構成される。 これらの部材が大量に出土していることから、それらがどのように 組み合わされるかを明らかにする必要がある。ここで、明確に高さ の異なる 4 種類の柱身があるので、礎盤と柱頭も同様に 4 種類あり、 高さの異なる 4 種類の柱の組み合せが存在したと考えられる。以下 では、各部材の寸法関係をもとに、4 種類の組み合せを明らかにす る。

礎盤は、部材の高さや上面直径などがまちまちであるので、それ らの寸法比較による分類が困難である。そこで、柱身の底面直径と 礎盤の上面直径の大小関係をもとに、礎盤と柱身の組み合わせの分 類をおこなう。つまり、礎盤の上面寸法は、組み合わさる柱身の底 面寸法の最小值より大きく、次に高い柱身の底面直径の最小值より 小さいと考え、寸法を算出した。このように礎盤と柱身の組み合わ せを求めると、最も高い柱身 (底面直径最小 $0.560 \mathrm{~m}$ 最大 $0.596 \mathrm{~m}$ ) には、上面直径 $0.560 \mathrm{~m}$ 以上の礎盤が組み合わされる。2 番目に高 い柱身 (底面直径最小 0.467 最大 $0.504 \mathrm{~m}$ ) には、上面直径 $0.467 \mathrm{~m}$ 以 上 $0.560 \mathrm{~m}$ 未満の礎盤が組み合わされる。3 番目に高い柱身 (底面 直径最小 $0.406 \mathrm{~m}$ 最大 $0.416 \mathrm{~m}$ ) には、上面直径 $0.406 \mathrm{~m}$ 以上 $0.467 \mathrm{~m}$ 未満の礎盤が組み合わされる。そして、最も低い柱身 (底面直径最 小 $0.340 \mathrm{~m}$ 最大 $0.402 \mathrm{~m}$ ) には、上面直径 $0.340 \mathrm{~m}$ 以上 $0.406 \mathrm{~m}$ 未満の 礎盤が組み合わされる。

一方、柱頭の底面直径は、柱身の上面直径よりも小さくなると推 測できる。ただし、イオニア式柱頭は、渦巻装飾が底面より低い位 置まで張り出しており、対角にあたる渦巻装飾同士の距離より円柱 の上面直径が大きいと、渦巻と円柱とがぶつかってしまう。した がって、イオニア式柱頭に接続する柱身の上面直径は、基本的に柱 頭底面直径 (最小 $0.345 \mathrm{~m}$ 最大 $0.408 \mathrm{~m}$ ) と同程度か、それ以下であ る必要がある。この条件を満たす柱身は、上面直径が最小 $0.284 \mathrm{~m}$ 最大 $0.341 \mathrm{~m}$ の最も低い柱身のみである。次に、コリント式柱頭は、 出土している 2 部材の底面直径がともに $0.400 \mathrm{~m}$ であるので、組み 合わされる柱身の上面直径は、 $0.400 \mathrm{~m}$ 以上となる。また、柱頭の 底面に 3 つのダボ穴があるため、柱身上面にも同様に 3 つのダボ穴 があると考えられる。これらの条件を満たす柱身は、最も高い柱身 のみである。最後に、ロータス・アカンサス式柱頭 (底面直径最小 $0.310 \mathrm{~m}$ 最大 $0.420 \mathrm{~m}$ ) と組み合わされる柱身を考える。ここで、ま だ組み合せが決定していない柱身は、2 番目と 3 番目に高い柱身で ある。直径の大小関係から柱頭と柱身の組み合せを考えると、底面 直径が $0.419 \mathrm{~m}$ より大きく $0.495 \mathrm{~m}$ 以下のロータス・アカンサス式柱 頭が 2 番目に高い柱身 (上面直径最小 $0.433 \mathrm{~m}$ 最大 $0.495 \mathrm{~m}$ ) と組み 合わされ、底面直径が $0.419 \mathrm{~m}$ 未満のロータス・アカンサス式柱頭 が 3 番目に高い柱身 (上面直径最小 0.370 最大 $0.419 \mathrm{~m}$ ) と組み合わ されたと考えられる。ただし、ロータス・アカンサス式柱頭は、部
材ごとにプロポーションがまちまちであるため、底面直径が $0.419 \mathrm{~m}$ 以下でも、背が高い部材が存在する。そこで、これらの柱頭は、底 面直径よりは柱全体の高さを重視して制作されたと考え、底面直径 $0.419 \mathrm{~m}$ 以下でも高さ $0.441 \mathrm{~m}$ 以上の部材は、 2 番目に高い柱と組み 合わされたと推定する。

以上より、4 種類の柱の組み合せが決定した。4 種類の柱の高 さを求めると、コリント式柱頭が載る最も高い柱が高さ $4.999 \mathrm{~m}$ 、 大きなロータス・アカンサス式柱頭が載る 2 番目に高い柱が高さ $4.207 \mathrm{~m}$ 、小さなロータス・アカンサス式柱頭が載る 3 番目に高い柱 が高さ $3.597 \mathrm{~m}$ 、そしてイオニア式が載る最も低い柱が高さ $2.700 \mathrm{~m}$ となる。

2）オーダーの復元 (表 1、図 8)

ここでは、スカエナエ・フロンスに立っていた列柱のオーダーを 復元する。まず、スカエナエ・フロンスが何階建であったかを考える。 出土部材をみると、アーキトレイブ・フリーズ部材は、高さ約 $0.3 \mathrm{~m}$ の部材と高さ約 $0.6 \mathrm{~m}$ の部材がある。また、ゲイソン部材は、部材 正面の浮彫装飾の有無により 2 種類に分類される。このように、アー キトレイブ・フリーズとゲイソンの部材が 2 種類ずつあるので、ス カエナエ・フロンスは 2 階建であると考えられる。また、高さの異 なる 4 本の柱があることから、1 層に 2 種類のオーダーがあった可 能性が高い ${ }^{15}$ 。

次に、4 種類の柱の位置を明らかにする。通常、2 階建のスカエ ナエ・フロンスでは、1 階に背の高いオーダーが、 2 階に背の低いオー ダーが造られる。スカエナエ・フロンスにニッチが造られている場 合、ニッチのオーダーと列柱のオーダーが異なる場合がある。その 場合、 1 階に限って言うと、ニッチのオーダーが列柱のオーダーよ り高くなる。ただし、2 階のオーダーに関しては、この通りではない。 柱を構成する各部材の分類結果から、最も高い柱が 4 本、2 番目 に高い柱が 7 本、 3 番目に高い柱が 11 本、最も低い柱が 6 本ある ことが分かった。ここで、各ニッチには 2 本ずつ、1 階あたり計 6 本の柱が立つことから、7 本以上ある 2 番目と 3 番目に高い柱は、 ニッチには立たないということになる。したがって、発見された部 材から判明した各柱の数とオーダーの大小関係とを合わせて柱の位 置関係を考えると、最も高い柱が 1 階のニッチに、2 番目に高い柱 が 1 階の列柱に、3 番目に高い柱が 2 階の列柱に、そして最も低い 柱が 2 階のニッチに立つという組み合せであったことが分かる。

さらに、柱の上に置かれる梁抢よび軒部材の位置を考える。アー キトレイブ・フリーズ部材については、高さ約 $0.6 \mathrm{~m}$ の部材が 1 階 へ、高さ約 $0.3 \mathrm{~m}$ の部材が 2 階へ配置されたと考えられる。ここで、 高さ約 $0.6 \mathrm{~m}$ の部材の中に、浮彫装飾のある部材とない部材とがあ るので、これらの位置を決定する。浮彫装飾のある部材の中に、90 度を挟む 2 面にモールディングがあるため、矩形ニッチの西側出隅 のポディウムに立つ柱の上か、ニッチの中に建てられた柱の上に置 かれたと判断される部材がある。一方、浮彫装飾のない部材の中に は、90 度を挟む 2 面にモールディングがあり、かつ片面に円弧が ついていることから、中央ニッチの西側出隅のポディウムに立つ柱 の上に据えられたと判断できる部材がある。浮彫装飾のある部材と ない部材の双方が、列柱の上に混在するとは考えらえれないので、 おそらく、浮彫装飾のある部材がニッチの中に立つ柱の上に配置さ れ、浮彫装飾のない部材が列柱の上へ配置されたと推測される。 
ゲイソン部材は、部材前面に浮彫装飾がある高さ平均 $0.309 \mathrm{~m}$ の 部材が 1 階へ、装飾がない高さ平均 $0.253 \mathrm{~m}$ の部材が 2 階へ配置さ れたと考えられる。シーマは、2 階のゲイソンの上に配置されたと 推測される。

以上より、スカエナエ・フロンスのオーダーが復元された。部材 の実測值より、それらの平均值を用いてオーダー各部の復元寸法を 割り出した（表 1)。1 階ニッチのオーダーの高さが $5.928 \mathrm{~m} 、 1$ 階 列柱のオーダーの高さが高さ $5.207 \mathrm{~m} 、 2$ 階列柱のオーダーが高さ $4.143 \mathrm{~m}$ 、そして 2 階ニッチのオーダーの高さが $3.246 \mathrm{~m}$ となる(図 8)。 3）ポディウムの復元

列柱部分のポディウムは、現在、上部コーニスを除いて最高 $1.442 \mathrm{~m}$ である。現在残っている最上段のポロスの上面に溝が付け られており、ここにはめ込むようにコーニスが置かれ、その上に列 柱が配置されたと推測される (写真 3 )。ここで、ポディウムの現在 の高さとニッチの中に置かれたペデスタルのコーニスを除いた高さ $1.328 \mathrm{~m}$ との差は $0.114 \mathrm{~m}$ であることから、両者はほぼ同じ高さであっ たと考えられる。そこで、列柱部分のポディウムは、高さ $1.442 \mathrm{~m}$ までポロス材を積み、その上にペデスタルのコーニスと同じ高さ 0.226m のコーニスを載せたと推定した。

1 階のゲイソンと 2 階の柱の間にもポディウムが造られたと考え られるが、こちらに関しては全く手がかりがない。他の劇場を見る と、スカエナエ・フロンスの 2 階のポディウムの高さが 1 階のポディ ウムの高さの半分程度になる例が多いので、メッセネも同様である と推定し、2 階列柱のポディウムの高さを $0.834 \mathrm{~m}$ とした ${ }^{16)}$ 。

2 階ニッチのポディウムに関しても、出土遺構や部材の中に手が かりが全くない。一般に、スカエナエ・フロンスのオーダーは、最 上階においてニッチと列柱との梁の高さを揃える。メッセネの場合 は、2 階が最上階であるので、この部分で梁の高さを揃えたと推測 される。しかし、1 階のニッチと列柱とでオーダーの高さが異なる ので、2 階で梁の高さを揃えるためには、2 階の列柱とニッチのポ ディウムの高さで全体の高さを調整する必要がある。ニッチ床面か ら列柱の 2 階柱頭上面までの高さは、 $11.303 \mathrm{~m}$ であるので、これか らニッチ 1 階のペデスタル、オーダーと 2 階の柱の高さを引くと、 $1.132 \mathrm{~m}$ となり、これをニッチ 2 階のポディウムの高さとして推定 した。

\section{4）柱の配置と柱間寸法 ( 図 11)}

ここでは、アーキトレイブ・フリーズの寸法を元に、柱の配置と 各柱の柱間真真間距離とを算出する。

アーキトレイブ・フリーズ部材の中で、全長が判明し、かつ円弧 がついているものが 1 つ発見されている。この部材の全長が $2.096 \mathrm{~m}$ であることから、半円形ニッチの側面へ回り込むポディウムの上に 載る柱は、この部材が届く位置、すなわち、ニッチの出隅部分のポ ディウムの上に据えられた柱の中心から $2 \mathrm{~m}$ ほどの位置に据えられ たと推定される（図 9)。

ここで、ポディウム上のその他の部分の柱配置を考える。これま でに発見されたアーキトレイブ・フリーズ部材の中で全長がわかっ ているものを実測したところ、No. 325 が全長 1.768 、No. 27 が全 長 2.096m、No. 960+988 が全長 2.053m である。柱と柱の真真間距 離は、アーキトレイブ・フリーズ部材の全長とほぼ同值であると考 えられることから、列柱の柱の真真間距離は、約 $1.7 \mathrm{~m} \sim$ 約 $2 \mathrm{~m}$ で
あると考えられる。

部材 No. 960+980 の両端に、隣の部材と平行に接続するようなク

表 1 オーダー各部の復元寸法

\begin{tabular}{|c|c|c|c|c|c|c|c|}
\hline \multirow{2}{*}{ ニッチ } & \multirow{2}{*}{$\begin{array}{l}\text { 寸法 } \\
\text { (m) }\end{array}$} & 最小値 & \multirow{2}{*}{$\begin{array}{l}\begin{array}{l}\text { データ } \\
\text { 数 }\end{array}\end{array}$} & \multirow{2}{*}{ 列柱 } & \multirow{2}{*}{$\begin{array}{l}\text { 寸法 } \\
\text { (m) }\end{array}$} & \multirow{2}{*}{\begin{tabular}{|l} 
最小値 \\
最大值
\end{tabular}} & \multirow{2}{*}{ 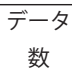 } \\
\hline & & 最大値 & & & & & \\
\hline \multirow{2}{*}{ 礎盤プリンス幅 } & \multirow{2}{*}{0.758} & 0.755 & \multirow{2}{*}{2} & \multirow{2}{*}{ 礎盤プリンス幅 } & \multirow{2}{*}{0.684} & 0.642 & \multirow{2}{*}{4} \\
\hline & & 0.760 & & & & 0.700 & \\
\hline \multirow{2}{*}{$\begin{array}{l}\text { 礎盤プリンス高 } \\
\text { さ }\end{array}$} & \multirow{2}{*}{0.135} & 0.134 & \multirow{2}{*}{2} & \multirow{2}{*}{ 礎盤プリンス高さ } & \multirow{2}{*}{0.126} & 0.109 & \multirow{2}{*}{4} \\
\hline & & 0.135 & & & & 0.140 & \\
\hline \multirow{2}{*}{ 礎盤上面直径 } & \multirow{2}{*}{0.596} & & \multirow{2}{*}{1} & \multirow{2}{*}{ 礎盤上面直径 } & \multirow{2}{*}{0.526} & 0.470 & \multirow{2}{*}{4} \\
\hline & & & & & & 0.556 & \\
\hline \multirow{2}{*}{ 礎盤高さ } & \multirow{2}{*}{0.240} & & \multirow{2}{*}{1} & \multirow{2}{*}{ 礎盤高さ } & 0188 & 0.156 & 4 \\
\hline & & & & & 0.180 & 0.212 & 4 \\
\hline 标自底而古役 & & 0.560 & 4 & 妵自底面直㣔 & & 0.467 & \\
\hline 玨身蚱面但径 & 0.574 & 0.596 & 4 & 枉身低面但径 & 0.491 & 0.504 & 7 \\
\hline 柱身高さ & 4057 & 4.034 & 3 & 柱身高士 & 3524 & & 1 \\
\hline & & 4.068 & & 恃身高さ & & & 1 \\
\hline 柱身上面直径 & 0.515 & 0.510 & 3 & 柱身上面直径 & 0452 & 0.433 & 4 \\
\hline 恃身上回但佳 & & 0.523 & & 恃身工四但任 & & 0.495 & \\
\hline & & 0.400 & 2 & & & 0.552 & 6 \\
\hline 玨頙氐面但径 & 0.400 & 0.400 & 2 & 枉頭氐面但径 & 0.582 & 0.600 & 6 \\
\hline 柱頭高士 & 0.567 & 0.652 & 2 & 柱䜺高士 & 0471 & 0.441 & 5 \\
\hline 恃頭同さ & $0.50 \%$ & 0.671 & 2 & 恃頭问さ & $0.4 / 1$ & 0.515 & 5 \\
\hline アーキトレイブ & 0412 & & 1 & アーキトレイブ底 & 0.381 & 0.372 & 2 \\
\hline 底面幅 & & & & & & 0.412 & \\
\hline フリーズト面饾 & $(0.534)$ & $(0.498)$ & (3) & フリーズ上面饾 & 0534 & 0.498 & $3+2>$ \\
\hline & & $(0.555)$ & & & & 0.555 & 3 \\
\hline アーキトレイブ & 0.367 & & 1 & アーキトレイブ高 & 0.334 & 0.260 & 4 \\
\hline 高さ & & & & t & & 0.370 & \\
\hline フリーズ高さ & 0.253 & & 1 & フリーズ高さ & 0.234 & 0.233 & 3 \\
\hline & & & & & & 0.235 & \\
\hline アーキトレイブ・ & 0.620 & & 1 & アーキトレイブ・ & 0592 & 0.587 & 3 \\
\hline フリーズ高さ & & & & フリーズ高さ & & 0.596 & \\
\hline コーニス高さ & 0.309 & 0.293 & 8 & フーース高士 & 0300 & 0.293 & 8 \\
\hline - - & & 0.320 & & 与一戊回し & & 0.320 & \\
\hline
\end{tabular}

2 階のオーダー各部の復元寸法

\begin{tabular}{|c|c|c|c|c|c|c|c|}
\hline \multirow{2}{*}{ ニッチ } & \multirow{2}{*}{$\begin{array}{l}\text { 寸法 } \\
\text { (m) }\end{array}$} & \multirow{2}{*}{\begin{tabular}{|l|} 
最小値 \\
最大値 \\
\end{tabular}} & \multirow{2}{*}{$\begin{array}{l}\text { データ } \\
\text { 数 }\end{array}$} & \multirow{2}{*}{ 列柱 } & \multirow{2}{*}{$\begin{array}{l}\begin{array}{l}\text { 寸法 } \\
\text { (m) }\end{array} \\
\end{array}$} & \multirow{2}{*}{\begin{tabular}{|l} 
最小値 \\
最大値
\end{tabular}} & \multirow{2}{*}{\begin{tabular}{|l}
\begin{tabular}{|l} 
データ \\
数
\end{tabular} \\
\end{tabular}} \\
\hline & & & & & & & \\
\hline \multirow{2}{*}{ 礎盤プリンス幅 } & \multirow{2}{*}{0.558} & & \multirow{2}{*}{1} & \multirow{2}{*}{ 礎盤プリンス幅 } & \multirow{2}{*}{0.591} & 0.572 & \multirow{2}{*}{10} \\
\hline & & & & & & 0.630 & \\
\hline \multirow{2}{*}{$\begin{array}{l}\text { 礎盤プリス高 } \\
\text { さ }\end{array}$} & \multirow{2}{*}{0.077} & & \multirow{2}{*}{1} & \multirow{2}{*}{ 礎盤プリンス高さ } & \multirow{2}{*}{0.12} & 0.099 & \multirow{2}{*}{10} \\
\hline & & & & & & 0.143 & \\
\hline \multirow{2}{*}{ 礎盤上面直径 } & \multirow{2}{*}{0.390} & & \multirow{2}{*}{1} & \multirow{2}{*}{ 礎盤上面直径 } & \multirow{2}{*}{0.428} & 0.406 & \multirow{2}{*}{11} \\
\hline & & & & & & 0.463 & \\
\hline \multirow{2}{*}{ 礎盤高さ } & \multirow{2}{*}{0.146} & & 1 & 礎盤高さ & 0.178 & 0.154 & 11 \\
\hline & & & & 啶篮同じ & $0.1 / 8$ & 0.234 & 11 \\
\hline 柱身底面直径 & 0.378 & 0.340 & 6 & 柱身底面直径 & 0411 & 0.410 & 3 \\
\hline " & & 0.402 & & 性身抟国旦任 & 0.411 & 0.416 & \\
\hline & & & & & & 2.906 & \\
\hline 恃身高心 & 2.329 & & 1 & 恃身同心 & 2.900 & 2.906 & 2 \\
\hline 柱身上面直径 & 0.313 & 0.284 & 6 & 柱身上面直径 & 0.399 & 0.370 & 6 \\
\hline 恃身上四目任 & 0.313 & 0.341 & 0 & 恃身工伹但任 & & 0.419 & \\
\hline 柱頭底面直径 & 0.365 & 0.345 & 5 & 柱頭底面直径 & 0.331 & 0.310 & 3 \\
\hline 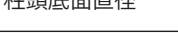 & & 0.408 & & 恃韻绕回旦任 & 0.301 & 0.374 & 3 \\
\hline 柱頭高士 & 0.148 & 0.141 & 5 & 柱頭高士 & 0394 & 0.363 & 3 \\
\hline 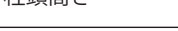 & 0.140 & 0.162 & 3 & 恃部问し & 0.294 & 0.425 & 3 \\
\hline アーキトレイブ & 0.330 & 0.321 & 2 & アーキトレイブ底 & 0.33 & 0.321 & 2 \\
\hline 底面幅 & 0.330 & 0.339 & 2 & 面幅 & 0.33 & 0.339 & 2 \\
\hline フリーズ上面幅 & 0.390 & 0.387 & 2 & フリーズト面幅 & 0.39 & 0.387 & 2 \\
\hline 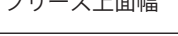 & 0.390 & 0.392 & & |ノリー人上囬临 & & 0.392 & \\
\hline アーキトレイブ & 0181 & 0.179 & 2 & アーキトレイブ高 & 0.181 & 0.179 & 2 \\
\hline 高さ & 0.101 & 0.182 & & t & 0.101 & 0.182 & 2 \\
\hline フリーズ高さ & 0.113 & 0.112 & 2 & フリーズ高さ & 0.113 & 0.112 & 2 \\
\hline 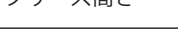 & & 0.113 & & 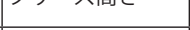 & & 0.113 & \\
\hline アーキトレイブ・ & 0293 & 0.291 & 2 & アーキトレイブ・ & 0293 & 0.291 & 2 \\
\hline フリーズ高さ & 0.293 & 0.295 & 2 & フリーズ高さ & 0.293 & 0.295 & 2 \\
\hline コーニス高さ & 0.253 & 0.230 & 12 & コーニス高さ & 0.253 & 0.230 & 12 \\
\hline & & 0.280 & & & & 0.280 & \\
\hline & & & & シーマ高さ & 0.197 & 0.185 & 4 \\
\hline & & & & & & 0.211 & \\
\hline
\end{tabular}




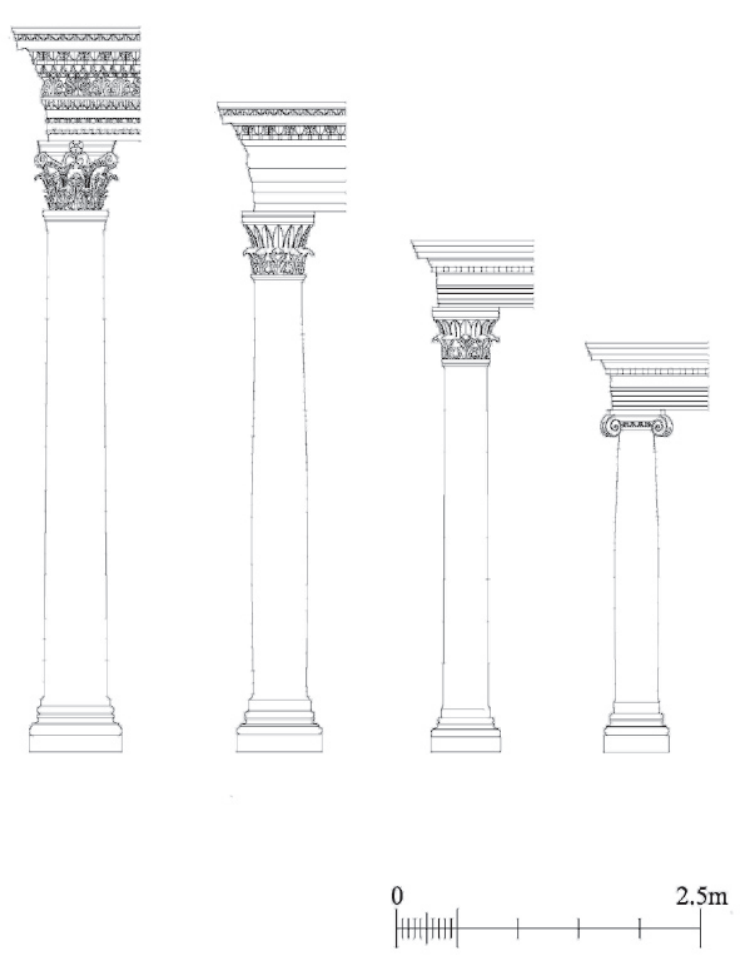

図 8 スカエナエ・フロンスの各部オーダー復元図

(左から順に、1 階ニッチ、1 階ポディウム、2 階ポディウム、2 階ニッチ)

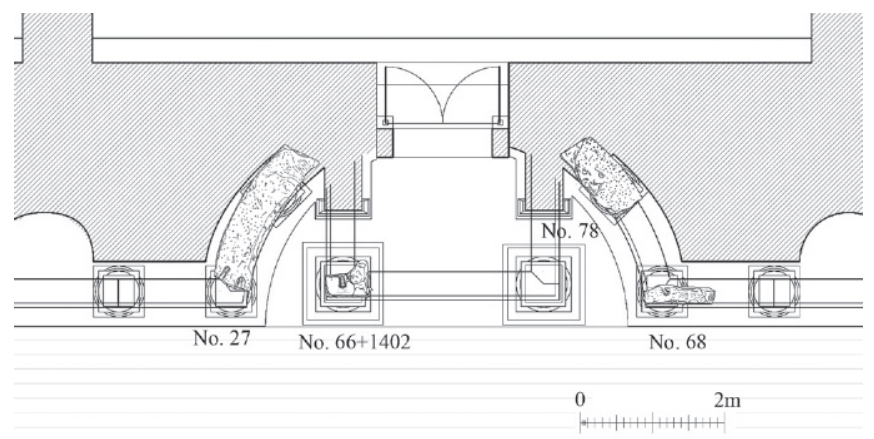

図 9 半円形ニッチ周辺のアーキトレイブ・フリーズの配置

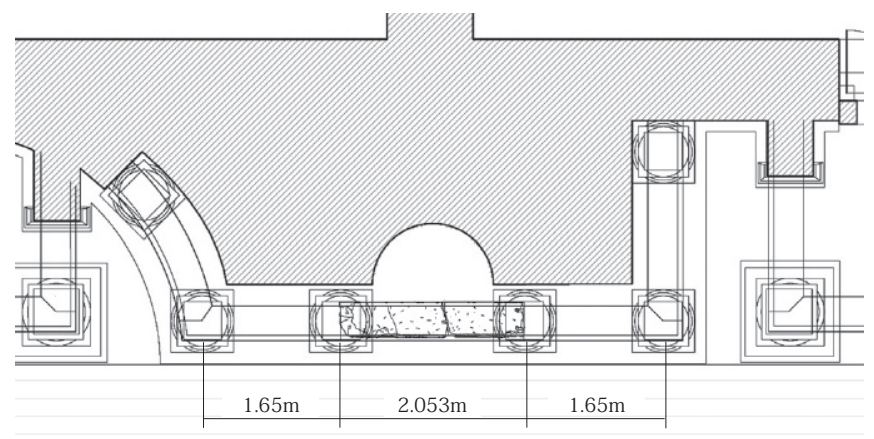

図 10 ニッチ間のポディウム上の柱・梁配置と柱間寸法
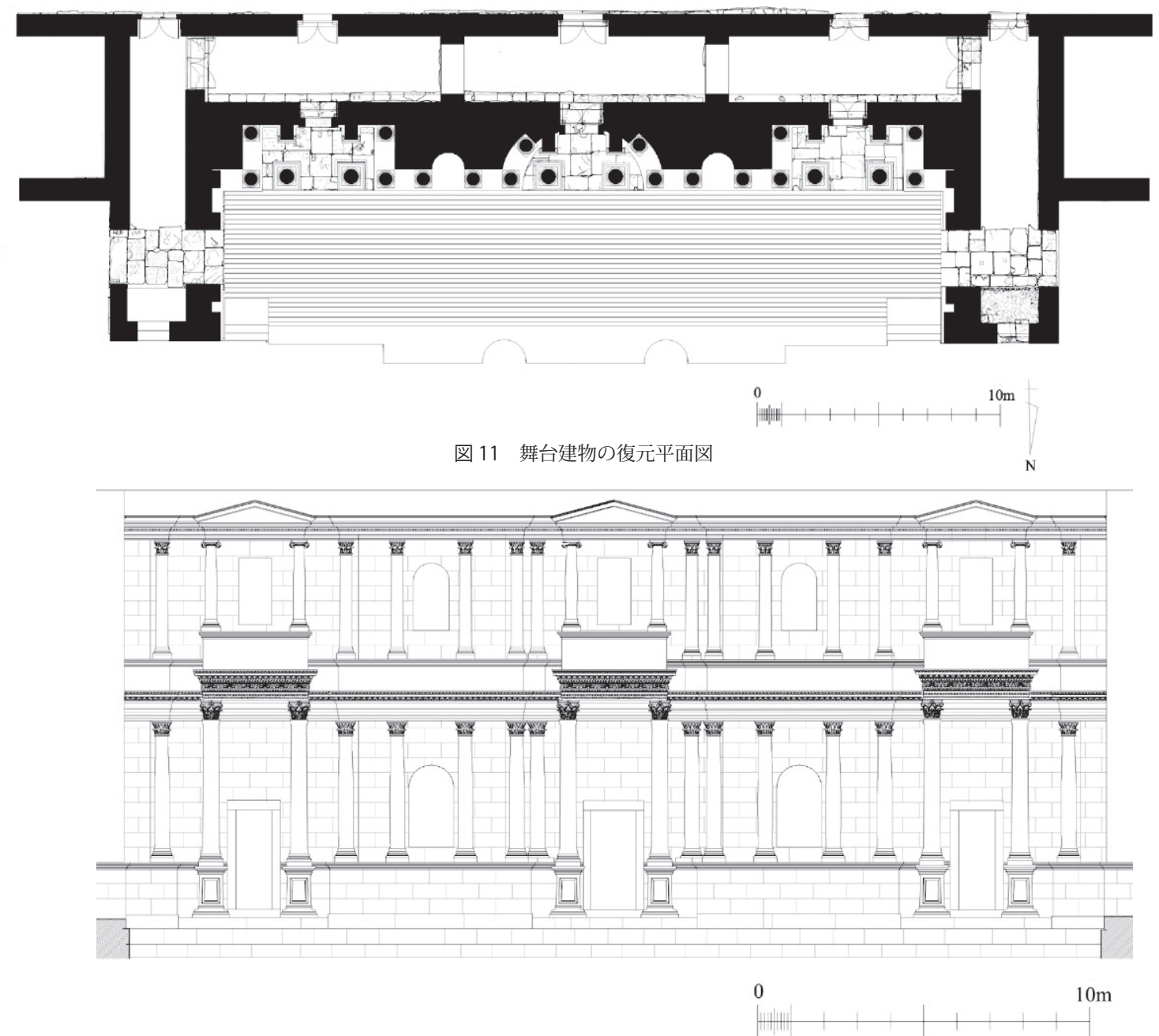

図 12 スカエナエ・フロンスの立面の復元試案 
ランプ穴があることから、この部材が載る柱の外側には、さらに 1 本ずつ柱が立っていたことが判明した。4 本以上の柱が一列に並ぶ のは、ニッチとニッチの間のポディウムの上のみである。この部分 のポディウムは全長 $6.06 \mathrm{~m}$ なので、出土部材の全長と合わせて考元 ると、ここには 4 本の柱が立ち、中央 2 本の柱の真真間距離が $2.053 \mathrm{~m}$ となり、左右 2 本の柱の真真間距離が約 $1.65 \mathrm{~m}$ となると考えられる （図 10）。他方、矩形ニッチの奥行きは、東ニッチが $2.58 \mathrm{~m} 、$ 西ニッ チが $2.61 \mathrm{~m}$ であるので、矩形ニッチに回り込むポディウムの上に立 つ列柱は、1 辺につき 1 柱間であったと考えられる。すると、柱の 真真間距離は、東ニッチで $2.089 \mathrm{~m}$ 、西ニッチで $2.119 \mathrm{~m}$ となる。

一般的に、スカエナエ・フロンスの列柱は、舞台両袖の出入り口 まで回り込み、開口部の両側には柱が配置される。しかし、メッセ ネの場合、仮にここまで柱が回り込むと、背後の壁が厚さ $1 \mathrm{~m}$ 弱と なり、 2 階建て $12 \mathrm{~m}$ 程度の高さまで立ち上がる場合、自立できない 可能性がある。したがって、この部分には厚さ $1.5 \mathrm{~m}$ 程度の壁が立 ちあがり、開口部の両側には、片蓋柱があったと推定した。

5) ニッチ

各ニッチの床面には、約 $1.2 \mathrm{~m}$ 角の 2 つのペデスタルが据えられ た設置痕があり、東ニッチには、実際にペデスタルのベースが残つ ていることから、中央扔よび西ニッチにも、同様にペデスタルが 2 つずつ据えられたと考元られる。ペデスタルは、ベース、本体部分、 そしてコーニスの 3 部材から成り、各部材が発見されている。ペデ スタル全体の高さは、 $1.554 \mathrm{~m}$ で、上面寸法は $1.050 \mathrm{~m}$ 角である。コー 二ス部材の上面にダボ穴が残っており、上面中央部分が粗仕上げと なっていることから、この上に柱が載せられていたと考兄られる。 1 階のニッチのオーダーの高さは $5.928 \mathrm{~m}$ であるので、ペデスタル と合わせた高さは、 $7.474 \mathrm{~m}$ となる。2つのペデスタルの設置痕の位 置から、それらの上に載っていた柱の柱間真真間距離は、中央ニッ チで $2.750 \mathrm{~m}$ 、東西ニッチで $2.651 \mathrm{~m}$ であったことがわかる。

東ニッチでは、片蓋柱の痕跡が発見されている。具体的には、出 入口から $0.247 \mathrm{~m}$ の位置に、長さ $0.516 \mathrm{~m}$ 、高さ $0.540 \mathrm{~m}$ のポロス材 が、壁と一体になるように置かれている。この石材が、壁から $0.290 \mathrm{~m}$ 迫り出していることから、この部分にポディウムをペデスタル状に 立ち上げ、化粧材を貼って仕上げ、その上に角柱の片蓋柱が載せら れたと推測される。片蓋柱は、各ニッチの出入口の両脇に造られ、 これらは、ニッチ前方のペデスタルに載る柱と同じ高さまで立ちあ がり、梁で接続されていたと考えられる ${ }^{17) 。 ~}$

\section{5-2. プロスケニオンの壁の復元}

プロスケニオンの壁は、現在オルケストラから高さ約 $1.00 \mathrm{~m} ま$ で残っているが、当時は舞台の高さ $1.228 \mathrm{~m}$ まで立ちあがり、こ の壁の一部を利用して舞台の床板を張っていたと考えられる。プロ スケニオンの壁は煉瓦造りで、表面には大理石の化粧材が貼られて いた。直径 $1.83 \mathrm{~m}$ 半円形ニッチが中央部に 2 つ設けられた。

\section{5-3. 舞台の復元}

舞台部分には、木造の床板が張られ、ニッチ床面と舞台床面が同 じ高さに揃えられたと考えられる。ニッチ前面の舞台に面する壁に、 ニッチ床面あるいはパラスケニオン床面の端部から前方へ下部の石 材列が飛び出し、段差となっている（写真 2)。この段差の上面か らニッチ床面までの高さは $0.270 \mathrm{~m} \sim 0.300 \mathrm{~m}$ である。この段差か らプロスケニオンの壁へ南北方向に、舞台を張るための床梁を架け
たと推測される。この時、舞台下に並べられたポロス材の再利用部 材の円柱が、この床梁の中間部分を支えていたと考えられる。

\section{5-4. ポストスケニオンと通路の復元}

ポストスケニオンは、3室に分かれていたが、抢そらく各室の行 き来はでき、通路のようになっていたと考元られる。各室間を仕切 る壁拉よび南側壁は、石灰岩で造られ、内部の壁はポロスで造られ ている。各室には外部と舞台、それぞれへ続く出入口があり、ここ には内開きの扉が入っていた。ポストスケニオンの上部構造は不明 であるが、階段の痕跡が見つからなかったので、1階建であっただ ろう。

また、舞台建物の東西両端には、全長約 $8 \mathrm{~m} 、$ 幅約 $2.4 \mathrm{~m}$ の通路 がある。この通路の北側には、舞台、東西両外側、そしてパラドス へ抜ける出入口があり、南側にも外部へ抜ける出入口が設けられて いる。役者はここを通り、舞台と控室、外部とを行き来していたと 推察される。ここにも階段の痕跡がないことから、1 階建であった と考えられる。

\section{6. 結論}

本研究によって、メッセネの劇場における後 2 世紀の舞台建物 の詳細がはじめて明らかになった。今回の研究で明らかになった点 をまとめると、以下のようになる。

後 2 世紀の舞台建物は、全長 $46.6 \mathrm{~m} 、$ 幅約 $15 \mathrm{~m}$ の建物で、前面 に全長 $29.47 \mathrm{~m}$ の木造の舞台があり、その背後に 2 階建てのスカエ ナエ・フロンスが立ち上がっていた(図12)。舞台建物には3つのニッ チがあり、中央が半円形、東西が矩形のニッチであった。ニッチには、 それぞれ 2 本の柱がペデスタルの上に立っており、後方に立つ角柱 の片蓋柱と梁で接続していた。スカエナエ・フロンスには、4種類 のオーダーが用いられ、ニッチの 1 階にコリント式オーダー、2 階 にイオニア式オーダー、列柱の 1 階に背の高いロータス・アカンサ ス式オーダー、2 階に背の低いロータス・アカンサス式オーダーが 使用されたと推測される。1 階と 2 階を比較すると、 1 階部分には より装飾的なオーダーが用いられていた。舞台建物の後方には、1 階建のポストスケニオンがあった。建物の東西には、長さ約 $8 \mathrm{~m} の$ 通路があり、ポストスケニオン、舞台、パラドスや外部へと続く出 入口が設けられていた。

一般に、劇場のスカエナエ・フロンスの列柱にはコリント式オー ダーやイオニア式オーダーが使用されるが、メッセネの劇場では、 さらにロータス・アカンサス式柱頭を加えた、多様なオーダーが使 用される珍しい例である。

\section{謝辞}

本研究は、平成 $21 \sim 23$ 年度日本学術振興科学研究費基盤 $(\mathrm{S})$ 課 題番号：20226012）(研究代表者: 伊藤重剛) の助成を得た。また、 平成 20 年度・前田記念工学振興財団 (吉武隆一) の助成を得た。 記して謝意を表する。

注

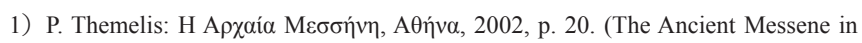
Greece).

2) Th. Sophoulis: Prakt, 1895 , p. 27 ; AM, 1895 , p. 375 ; AA, 1896 , p. 73 , pp. $453-$ 454 
3) G. Oikonomos: Prakt, 1909, pp. 201-205; 1925, pp. 55-66; BCH, 1925, pp. 453454

4) A. K. Orlandos: Report of Excavation , Ergon, 1959, pp. 143-148; 1960, pp. 110117; 1961, 159-166; 1963, pp. 119-125; 1964, pp. 88-102; 1965, pp. 90-101; 1970, pp. $97-132 ; 1973$, pp. $67-81 ; 1974$, pp. 79-82

5）メッセネ考古学協会によるメッセネの発掘に関しては、以下に報告され

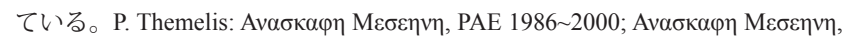
Ergon, 1987 2002

6）劇場の発掘報告は、以下の年報を参照。P. Themelis: П.A.E. 1987, pp. 73-79,

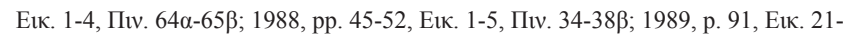

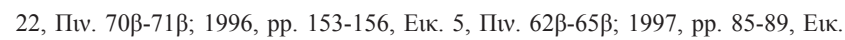

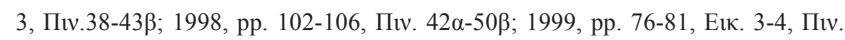

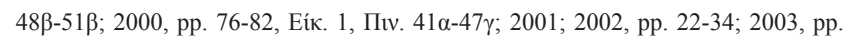
26-28; 2004, pp. 28-29; 2005, pp. 39-48; 2006, pp. 32-43.

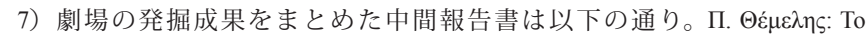

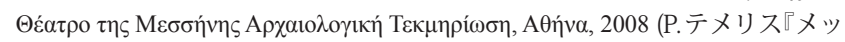
セネの劇場の考古学的検証』(ギリシア語 ))

8）熊本大学によるメッセネの劇場の調査報告は、以下の通り。吉武隆一、伊 藤重剛、岩田千穂、『地中海古代都市の研究 (133) メッセネにおける劇場調 査報告 2010(1) スカエナエ・フロンスの柱頭』、日本建築学会研九州支部研 究報告、50 号 3、pp.637-640、2011 年 3 月、岩田千穂、吉武隆一、伊藤重 剛、『地中海古代都市の研究 (134) メッセネに打りる劇場調査報告 2010(2)、 「ローマ時代スケーネの復元試案」日本建築学会九州支部研究報告、50 号 3、pp.641-644、2011 年 3 月、吉武隆一、伊藤重剛、岩田千穂ほか、『地中 海古代都市の研究 (128) メッセネにおける劇場調査報告 2009(1) 平面』、日 本建築学会九州支部研究報告、第 49 号 3(計画系)、pp.585-588、2010 年 3 月、ソクンティー・セイン、吉武隆一、伊藤重剛、岩田千穂ほか、『中海古 代都市の研究 (129) メッセネにおける劇場調査報告2009(2) スケーネ』、日 本建築学会九州支部研究報告、第 49 号 3(計画系)、pp.589-592、2010 年 3 月、岩田千穂、伊藤重剛、吉武隆一ほか、『地中海古代都市の研究 (130) メッ セネにおける劇場調査報告 2009(3) スケーネ部材』、日本建築学会九州支部 研究報告、第 49 号 3(計画系)、pp.593-596、2010 年 3 月、谷晧司、伊藤重 剛ほか、『地中海古代都市の研究 (123) 古代都市メッセネにおける劇場調査 報告 2008(1) 概要』、日本建築学会九州支部研究報告、第 48 号 (計画系)、 pp.773-776、2009 年 3 月、中之丸諭志、伊藤重剛ほか、『地中海古代都市の 研究 (124) 古代都市メッセに打ける劇場調査報告 2008(2) 出土部材』、日本 建築学会九州支部研究報告、第 48 号 (計画系)、pp.777-780、2009 年 3 月

9）オルケストラの背後にある建物は、通常スケーネと呼ばれ、列柱やニッチ などが配置された部分はスカエナエ・フロンスと乎ばれる。スカエナエ・ フロンスは厳密には建物ファサードを指す。ここでは、舞台やスカエナエ・ フロンスを構成する建物を総称して舞台建物と呼び、スカエナエ・フロン スの前にあるステージを舞台と呼ぶ。

10) M. Bieber: The History of the Greek and Roman Theater, Princetone, 1971; F. Sear: Roman Theatres, Oxford, 2006

11) E. Fiechter: Das Dionysos-Theater in Athen I. Die Ruine, Stuttgart, 1935; G. Caputo: Il Theatro di Sabratha e L'Architettura Teatrale Africana, Monografie di Archeologia Libica - IV , "L'Erma" di Bretschneider, Roma, 1959

12) Ginouves のギリシア・ローマ建築に関する事典によると、通常のイオ ニア式柱頭は Normal Ionic Capital、斜め 45 度に渦巻装飾が飛び出すイオ ニア式柱頭は Four Sided Ionic Capital と称される。 R. Ginouves, Dictionnarie Methodique de L'Architecture Grecque et Tomain 2, Ecole Francaise D'Athens de Rome, 1992, p. 85, Pl. 44

13）ロータス・アカンサス式柱頭は、おそらくロータス式柱頭とコリント 式柱頭を組み合せたもので、アテネの風の塔のポーチや、アグリッパの 音楽堂のポーチに使われている。J. Travlos: Bildlexikon zur Topographie des Antiken Athen, Tübingen, 1971, pl. 477. また、スカエナエ・フロンスに使われ たかどうかは不明ながら、ディオニソス劇場の近くからも見つかっている。 E. Fiechter, op.cit., Abb. 14. さらに、コリントやスパルタでも出土している。

14）出土したアーキトレイブ・フリーズには、ファスキアの 1 段目と 2 段目 の間に縄目文が、2段目と 3 段目の間に玉縁が、4 段目に心鏃装飾 (heartand-dart) が施されている。フリーズ部分には、パルメットとアカンサスの 浮彫が交互にあり、最上部に卵鏃装飾 (egg-and-dart) とビードが施されてい る。

15） 2 階建てのスカエナエ・フロンスでスカエナエ・フロンスのニッチ部分 と列柱部分で柱の高さが違う例は、メリダ、イグウィウム、ドウッガなど
の劇場が挙げられる。F. Sear: op.cit., Fig. 20, 21, PLATE. 90

16） 2 階建てのスカエナエ・フロンスをもつ劇場の 1 階と 2 階のポディウム の高さを以下に 3 例挙げる。メリダの劇場のスカエナエ・フロンスのポディ ウムの高さは、 1 階が $2.49 \mathrm{~m} 、 2$ 階が $1.38 \mathrm{~m}$ (1 階の $55.42 \%$ )、カルタゴ・ノ ヴァの劇場のスカエナエ・フロンスのポディウムの高さは、1 階が $1.85 \mathrm{~m}$ 、 2 階が $0.92 \mathrm{~m}$ (1 階の $49.73 \%$ ) イグヴィウムの劇場のスカエナエ・フロンスの ポディウムの高さは、1 階が $1.65 \mathrm{~m} 、 2$ 階が $0.83 \mathrm{~m}$ (1 階の 50.30\%) である。F. Sear: op.cit., p. 35, TABLE 3.12.

17）スカエナエ・フロンスに3つのニッチが造られる場合、ニッチの中の柱は、 列柱から独立している場合がある。最も顕著な例を挙げると、ボスラ、才 ランジュなどの劇場で、スカエナエ・フロンスの壁の前に立つ列柱部分は 3 階建であるが、3つのニッチは 2 階建となっている。これは、ニッチのオー ダーは列柱のオーダーから構造的に独立していることを示している。2 階 建のスカエナエ・フロンスをもつ劇場の中で列柱部分とニッチの中の柱の 高さが異なる例としては、メリダ、イグウィウム、ドゥッガなどの劇場が 挙げられる。メリダは、中央のニッチのみ高い柱を使用しているが、イグウィ ウム、ドゥッガでは、3つのニッチすべてで列柱より高い柱を使用している。 F. Sear: op.cit. , Fig. 20, 21, PLATE. 67, 98, 99

図版出典

写真 1 メッセ不考古学協会撮影

写真 2,3 伊藤重剛撮影

図1 メッセ不考古学協会作成

図2 12 著者作成

（2011年12月 9 日原稿受理，2012年 4 月27日採用決定） 